\title{
Additive and additive-by-additive genetic variability of productive traits in laying hens
}

\section{T. Szwaczkowski}

\author{
Department of Genetics and Animal Breeding, \\ August Cieszkowski Agricultural University \\ Wolyniska 33, 60-637 Poznań. Poland
}

(Received 16 September 1998; accepted 19 March 1999)

\begin{abstract}
The additive and additive-by-additive genetic variance components of productive traits in two strains of laying hens were estimated. A total of 8035 individuals (base and recorded) from eleven generations were included in the analysis. Body weight, age at sexual maturity, average egg weight and initial egg production were considered. Before the estimation of the variance component, modeling of fixed effects (generation and hatch period) and covariables were performed. The data were transformed by use of the Box-Cox method. The DFREML algorithm under a single trait animal model was employed. It was concluded that additive-by-additive epistasis effects are not important for the studied performance traits. The results also indicate that deviations from normality influence the magnitude of variance component estimates in a highly indirect manner. This leads to an increase of heritability estimates.
\end{abstract}

KEY WORDS: animal model, epistasis, laying hens, variance components

\section{INTRODUCTION}

Poultry breeding programs are aimed at improving the genetic potential for egg production through selection and mating plans. Hence, the considerations on optimization of genetic improvement have concentrated on the utilization of both additive and nonadditive genetic effects. Nonadditive genetic variation can be further divided into dominance (as interaction of genes at the same locus) and epistatic variance (as interaction of genes at two or more loci). 
There are several reasons for estimating nonadditive genetic variances (see e.g. Wei and Van der Werf, 1993): an unbiased estimation of heritability, more accurate prediction of breeding values, usage of nonadditive genetic effects in crossbreeding or special mating strategy. Many crossbreeding experiments, performed in laying hen populations, indicated an important role of the nonadditive genetic effects in egg production (Sheridan and Randall, 1977; Flock et al., 1991), egg weight (Fairfull et al., 1983; Flock et al., 1991), age at sexual maturity (Abplanalp et al., 1984) and body weight (Flock et al., 1991). Nonadditive genetic effects are, first of all, connected with the heterosis phenomenon. However, investigations conducted in purebred livestock populations resulted in the registration of relatively large, nonadditive genetic variability of some productive traits (Hoeschele, 1991; Fuerst and Soelkner, 1994). From a theoretical point of view, the estimation of nonadditive genetic variances may be performed using the classical sire and dam model. Thus, these variance estimates may be expressed as some functions of dam and sire variance components (see e.g. Lin and Lee, 1989; Tempelman and Burnside, 1990). In practice, this procedure of obtaining nonadditive genetic variance estimates seems to be questionable.

A more accurate approach for estimating these variance estimates is provided by the currently applied restricted maximum likelihood method (REML) (Patterson and Thompson, 1971) under an individual animal model (Quaas and Pollak, 1980; Henderson, 1988). REML estimation of variance components under an animal model is computationally demanding. However, this approach has several advantages (compared to the conventional approach), which have been discussed by Wężyk and Szwaczkowski (1997). Generally, the investigation of variability of gene interactions is difficult because the proportions of variance shared by relatives may be small and confounded by other genetic or environmental effects.

The present paper is a continuation of studies by Szwaczkowski (1995). The investigations have been carried out on the same laying hen populations. The dominance genetic variance estimates obtained by use of REML under an animal model were negligible.

The objective of this study was to estimate direct additive and nonadditive genetic variances of productive traits in laying hens.

\section{MATERIAL AND METHODS}

\section{Data}

The data, recorded between 1982 and 1992 , were provided by the Department of Poultry Breeding of the Polish Central Animal Breeding Office from the Pedigree Laying Hen Farm in Iwno. A total of 8035 individuals of two strains (White 
Leghorn denoted as $\mathrm{H77}$, and New Hampshire denoted as N88) was included. In all, 4352 recorded birds and 397 base (unrecorded) birds of $\mathrm{H} 77$ and 2968 recorded birds and 318 base (unrecorded) birds of N88 were analyzed. The collected data have an identical structure for both strains. All the individuals studied in 1992 (2963 individuals of $\mathrm{H} 77$ and 1976 individuals of N88) as well as their ancestors (dams) back to 1982 were recorded. Dams initiated in 1981 and all sires were treated as base animals.

The following traits were included:

- body weight at 18 th week of age (in grams) [BW],

- age at sexual maturity (in days) [ASM],

- average egg weight between 33rd and 35th week of age (in grams) [AEW],

- initial egg production (in pcs) [IEP].

No inbreeding was registered in these strains. The characteristics of the dataset are given in Table 1 .

TABLE 1

Description of data

\begin{tabular}{lccccc}
\hline & \multicolumn{5}{c}{ Strains } \\
\cline { 2 - 3 } & \multicolumn{3}{c}{ H77 } & & N88 \\
\cline { 2 - 3 } & mean & SD & mean & SD \\
\hline BW,g & 1273 & 152 & 1704 & 196 \\
ASM, g & 165 & 17 & 163 & 13 \\
AEW, g & 59.04 & 3.20 & 58.71 & 3.09 \\
IEP, pcs & 58.33 & 22.14 & 56.62 & 16.63 \\
\hline
\end{tabular}

Exploratory analysis

Two fixed factors were considered to be important: generation (year) with eleven levels, and hatch periods with four levels. Preliminary variance analysis was performed in a fixed linear model for cross-classified experimental design (including the year $\mathrm{x}$ hatch period interaction).

Moreover, dependencies (regression coefficients) between some traits were also evaluated. Age at sexual maturity and body weight were used as covariables for initial egg production and egg weight. The results of exploratory analysis are summarized in Table 2.

\section{Transformations of data}

First, the skewness and kurtosis of trait distribution were examined. The BW (for strain N88), AEW and IEP show negative skewness (other traits show posi- 
TABLE 2

Results of preliminary analysis and data transformation included in the mixed linear model

\begin{tabular}{lcccc}
\hline Strains & Traits & Fixed effects & Covariables & $\begin{array}{c}\text { Values t for Box-Cox } \\
\text { transformation }\end{array}$ \\
\hline H77 & BW & G & - & +0.90 \\
& ASM & G & - & -0.40 \\
& AEW & G & BW, ASM & +1.80 \\
N88 & IEP & G & BW, ASM & +0.95 \\
& BW & G, H, G*H & - & +1.40 \\
& ASM & G, H, G*H & $---{ }^{*}$ & -3.20 \\
& AEW & G, H & BW, ASM & +0.90 \\
& IEP & G & BW, ASM & +2.40 \\
\hline
\end{tabular}

$\mathrm{G}$ - the fixed effect of generation, $\mathrm{H}$ - the fixed effect of hatch period, $\mathrm{G}^{*} \mathrm{H}$ - the fixed effect of generation $\mathrm{x}$ hatch period interaction

tive skewness), whereas BW and IEP (for strain N88) show negative kurtosis. To reduce the non-normality and heterogeneity of error variance (and in consequence, additivity of the linear model), the Box-Cox transformation (Box and Cox, 1964) was employed. It should be noted that transformation of a non-normally distributed trait may improve the linearity of genotypic regression and increase heritability. This power transformation technique is expressed as follows:

$$
\begin{array}{lr}
y(t)=\frac{y^{t}-1}{t G_{y}^{t-1}} & \text { for } t \neq 0 \\
y(t)=\log y & \text { for } t=0
\end{array}
$$

where:

$y(t)$ is the transformed variable (trait) for a given parameter $t$, $\mathrm{y}$ is the untransformed variable,

$\mathrm{t}$ is the known parameter,

Gy is the geometric mean of untransformed variable.

To find the optimal $t$ the quasi-iterative procedure for minimizing skewness (first analyzed parameter) and kurtosis (second analyzed parameter) is used (see e.g. Strabel and Szwaczkowski, 1997). Both the transformed and untransformed data were used in estimating variance components. To enable comparison of results between different data-sets (different traits, transformed and untransformed) each observation was divided by the mean. 


\section{Model}

To estimate the direct additive and additive-by-additive genetic variance components the following single trait mixed model is used:

where:

$$
y=X b+Z(a+f)+e
$$

$\mathrm{y}$ is the $\mathrm{nx} 1$ observation vector,

$\mathrm{b}$ is ap $\mathrm{x} 1$ vector of unknown fixed effects or covariables (more details for each trait are given in Table 2),

$\mathrm{a}$ is aq $\mathrm{x} 1$ vector of unknown random additive genetic effects,

$f$ is aq $\times 1$ vector of unknown random additive-by-additive genetic effects,

$\mathrm{e}$ is an $\mathrm{x} 1$ vector of random error effects,

$\mathrm{X}$ and $\mathrm{Z}$ are the $\mathrm{n} \times \mathrm{p}$ and $\mathrm{n} \mathrm{x}$ q design matrices relating the observations to their fixed effects, and covariables as well as random effects, respectively.

The first and second moments of the model were assumed to be the following:

$$
\begin{aligned}
& \mathrm{E}\left[\begin{array}{l}
\mathrm{y} \\
\mathrm{a} \\
\mathrm{f} \\
\mathrm{e}
\end{array}\right]=\left[\begin{array}{c}
\mathrm{Xb} \\
0 \\
0 \\
0
\end{array}\right] \\
& \mathrm{D}\left[\begin{array}{l}
\mathrm{y} \\
\mathrm{a} \\
\mathrm{f} \\
\mathrm{e}
\end{array}\right]=\left[\begin{array}{cccc}
\mathrm{V} & \mathrm{ZA} \sigma_{a}^{2} & \mathrm{ZF} \sigma_{f}^{2} & \mathrm{I} \sigma_{c}^{2} \\
\mathrm{AZ} \sigma_{a}^{2} & \mathrm{~A} \sigma_{a}^{2} & 0 & 0 \\
\mathrm{AF} \sigma_{f}^{2} & 0 & \mathrm{~F} \sigma_{f}^{2} & 0 \\
\mathrm{I} \sigma_{e}^{2} & 0 & 0 & \mathrm{I} \sigma_{\underline{e}}^{2}
\end{array}\right]
\end{aligned}
$$

where:

$\mathrm{V}=\mathrm{ZAZ} \mathrm{Z}_{a}^{2}+\mathrm{ZFZ} \mathrm{\sigma}^{2}+\mathrm{I} \sigma_{e}^{2}$

$A$ is the $q \times q$ additive genetic relationship matrix,

$\mathrm{F}$ is the $\mathrm{q} \times \mathrm{q}$ additive-by-additive genetic relationship matrix which is calculated as the Hadamard product of A with itself (i.e. $f_{i j}=\left\{a_{i j}^{2}\right\}$ ),

I is an identity matrix of order $n$, $\sigma_{a}^{2}, \sigma_{f}^{2}, \sigma_{e}^{2}$ are the additive, additive-by-additive and error variances.

\section{Estimation of variance components}

The variance component estimates were obtained by application of the derivative-free restricted maximum likelihood (DFREML) algorithm described by Graser et al. (1987) for one random factor. This procedure was extended by Meyer 
(1989) to include additional random effects. The DFREML package programs of Meyer (1993) were used to estimate additive genetic, additive-by-additive genetic, and error variances. Additionally, estimation of additive-by-additive genetic variance requires the inverted relationship matrix $\mathrm{F}^{-1}$. The algorithm for inversion of this matrix described by Van Raden and Hoeschele (1991) is used here.

The convergence criterion was $1 \times 10^{-6}$ the variance of twice the logarithms of the likelihood in the simplex.

\section{RESULTS AND DISCUSSION}

The results of exploratory analysis were studied first (Table 1). It showed different incidence matrices for fixed effects on single traits (particularly in N88). Moreover, these results also indicated a relatively large difference in distributions of the same traits of both strains (see value $t$ - Table 2). In general, both strains kept under the same environmental conditions showed differences in the degree of reaction to changes of hatches and generations.

Table 3 lists estimates of direct additive and additive-by-additive genetic variances and error variance as well as respective heritability estimates ( $h_{c}^{2}$ and $h_{a c}^{2}$ ) with their standard errors. Generally, the estimates of additive-by-additive variances and, in consequence $\mathrm{h}_{u u}^{2}$, were uniformly near zero (the variance estimates were less than 0.0001, except of BW and ASM in strain N88). In the case of ASM in strain $\mathrm{N} 88$, all three variance estimates are very low compared to analogous estimates for other traits. It should be noted that similar magnitudes of dominance genetic variance estimates for these traits of the same data were obtained in earlier studies (Szwaczkowski, 1995). Analogous investigations concern three lines of laying hens, conducted by Wei and Van der Werf(1993), and indicate a relatively large proportion of dominance variance in phenotypic variance, for instance from 0.11 to 0.20 (for egg number) and from 0.02 to 0.13 (for egg weight).

To our knowledge, no animal model-REML estimates of additive-by-additive genetic variance for laying hen performance traits are currently available, so discussion is unavoidably restricted to general considerations concerning mainly analysis of epistatic effects in crossbreeding experiments. Fairfull and Gowe (1993) reviewed the major role of epistasis for egg production in chickens, whereas other authors (Eisen et al., 1967) concluded a minor influence of nonadditive gene action on other traits, for example body weight. An evaluation of non-additive genetic effects in crossbreeding experiments is relatively simpler than in purebred populations. Generally, the effects are obviously larger than within selected lines. Moreover, their estimation is carried out by contrasts between the respective combinations of parent and crossbreed groups. In this case, many nonadditive genetic effects may be simultaneously estimated (e.g. dominance, additive by dominance, 
(1989) to include additional random effects. The DFREML package programs of Meyer (1993) were used to estimate additive genetic, additive-by-additive genetic, and error variances. Additionally, estimation of additive-by-additive genetic variance requires the inverted relationship matrix $\mathrm{F}^{-1}$. The algorithm for inversion of this matrix described by Van Raden and Hoeschele (1991) is used here.

The convergence criterion was $1 \times 10^{-6}$ the variance of twice the logarithms of the likelihood in the simplex.

\section{RESULTS AND DISCUSSION}

The results of exploratory analysis were studied first (Table 1). It showed different incidence matrices for fixed effects on single traits (particularly in N88). Moreover, these results also indicated a relatively large difference in distributions of the same traits of both strains (see value $t$ - Table 2). In general, both strains kept under the same environmental conditions showed differences in the degree of reaction to changes of hatches and generations.

Table 3 lists estimates of direct additive and additive-by-additive genetic variances and error variance as well as respective heritability estimates $\left(h_{c}^{2}\right.$ and $h_{a d}^{2}$ ) with their standard errors. Generally, the estimates of additive-by-additive variances and, in consequence $\mathrm{h}_{u u}^{2}$, were uniformly near zero (the variance estimates were less than 0.0001, except of BW and ASM in strain N88). In the case of ASM in strain $\mathrm{N} 88$, all three variance estimates are very low compared to analogous estimates for other traits. It should be noted that similar magnitudes of dominance genetic variance estimates for these traits of the same data were obtained in earlier studies (Szwaczkowski, 1995). Analogous investigations concern three lines of laying hens, conducted by Wei and Van der Werf(1993), and indicate a relatively large proportion of dominance variance in phenotypic variance, for instance from 0.11 to 0.20 (for egg number) and from 0.02 to 0.13 (for egg weight).

To our knowledge, no animal model-REML estimates of additive-by-additive genetic variance for laying hen performance traits are currently available, so discussion is unavoidably restricted to general considerations concerning mainly analysis of epistatic effects in crossbreeding experiments. Fairfull and Gowe (1993) reviewed the major role of epistasis for egg production in chickens, whereas other authors (Eisen et al., 1967) concluded a minor influence of nonadditive gene action on other traits, for example body weight. An evaluation of non-additive genetic effects in crossbreeding experiments is relatively simpler than in purebred populations. Generally, the effects are obviously larger than within selected lines. Moreover, their estimation is carried out by contrasts between the respective combinations of parent and crossbreed groups. In this case, many nonadditive genetic effects may be simultaneously estimated (e.g. dominance, additive by dominance, 
TABLE 3

The additive genetic and additive-by-additive genetic and error variance estimates (x1000) as well as respective ratios of variance component estimates to phenotypic variance estimates ( \pm standard errors) for transformed and untransformed performance traits in laying hens

\begin{tabular}{|c|c|c|c|c|c|c|c|}
\hline \multirow[t]{2}{*}{ Strains } & \multirow[t]{2}{*}{ Traits } & & \multicolumn{3}{|c|}{ Variance component estimates } & \multicolumn{2}{|c|}{ Heritability estimates } \\
\hline & & & $\mathrm{s}_{\mathrm{a}}^{2}$ & $s_{i}^{2}$ & $\mathrm{~s}_{\mathrm{e}}^{2}$ & $\mathrm{~h}_{\mathrm{a}}^{2}(\mathrm{se})$ & $\mathrm{h}_{\mathrm{aa}}^{2}(\mathrm{se})$ \\
\hline \multirow[t]{8}{*}{$\mathrm{H} 77$} & BW & $a$ & 2.8449 & 0.0000 & 8.9082 & $0.2420(0.0386)$ & 0.0000 \\
\hline & & b & 0.0318 & 0.0000 & 0.1978 & $0.1386(0.0274)$ & 0.0000 \\
\hline & ASM & $\mathrm{a}$ & 2.2063 & 0.0000 & 7.4527 & $0.2960(0.0394)$ & 0.0000 \\
\hline & & b & 0.0065 & 0.0000 & 0.0160 & $0.2909(0.0398)$ & 0.0000 \\
\hline & AEW & a & 0.6286 & 0.0000 & 2.1955 & $0.2226(0.0325)$ & 0.0000 \\
\hline & & $\mathbf{b}$ & 2.0001 & 0.0000 & 6.9809 & $0.2227(0.0325)$ & 0.0000 \\
\hline & IEP & $\mathbf{a}$ & 3.6149 & 0.0000 & 39.2595 & $0.0843(0.0256)$ & 0.0000 \\
\hline & & $\mathbf{b}$ & 0.9095 & 0.0000 & 9.0066 & $0.0917(0.0261)$ & 0.0000 \\
\hline \multirow[t]{8}{*}{ N88 } & $\mathrm{BW}$ & $\mathbf{a}$ & 0.4631 & 0.0056 & 7.5822 & $0.0575(0.0201)$ & $0.0007(0.0013)$ \\
\hline & & $\mathrm{b}$ & 6.1068 & 0.1426 & 10.1317 & $0.3728(0.0647)$ & $0.0087(0.0092)$ \\
\hline & ASM & $\mathbf{a}$ & 0.1388 & 0.0440 & 4.4023 & $0.0302(0.0124)$ & $0.0096(0.0089)$ \\
\hline & & $\mathrm{b}$ & 0.0011 & 0.0004 & 0.0032 & $0.2380(0.0655)$ & $0.0785(0.0209)$ \\
\hline & AEW & $\mathbf{a}$ & 0.6795 & 0.0000 & 1.6487 & $0.2905(0.0513)$ & 0.0000 \\
\hline & & $\mathrm{b}$ & 0.0439 & 0.0000 & 0.0993 & $0.3054(0.0651)$ & 0.0000 \\
\hline & IEP & a & 0.5309 & 0.0000 & 26.5793 & $0.0196(0.0089)$ & 0.0000 \\
\hline & & $b$ & 3.0964 & 0.0000 & 84.7533 & $0.0352(0.0117)$ & 0.0000 \\
\hline
\end{tabular}

note on symbols: $\mathrm{a}$ - the results for untransformed data, $\mathrm{b}$ - the results for transformed data 
dominance by dominance etc.). In analyses of non-crossbreeding populations the genetic effects are treated as random. Their prediction requires the estimation of respective variance components (associated with computation of the inversion of relationship matrices). However, it is now computationally rather impossible to obtain estimates of several genetic variances using REML under an animal model.

The study was performed on selected strains. However, these productive traits (not always positively correlated) were included in the selection index. This is the main reason for very low additive-by-additive genetic variances of these traits. More details concerning the rules of breeding strategies in laying hens in Poland are given by Wężyk (1978) and Wężyk and Szwaczkowski (1997).

Generally, the heritability estimates $\left(h_{a}^{2}\right)$ of analyzed traits are similar to those obtained in recent studies (Rabsztyn, 1990; Besbes et al., 1993; Szwaczkowski and Wężyk, 1994). As expected, the lowest $h_{d}^{2}$ estimates have been obtained for IEP. It should be stressed that inclusion of the additive-by-additive genetic effects in the model modified heritability (in a narrow sense) estimates. Analyses of a simpler model (with the same incidence matrices for fixed effects, and additive genetic effects) were performed in an earlier study (Szwaczkowski, 1995). In this case, $\mathrm{BW}, \mathrm{AEW}$ (for H77 strain) and IEP (for N88 strain) $h_{a}^{2}$ estimates for the simple model were higher compared to the results obtained in the present study. In other cases, the respective estimates were similar or lower than in the simple model. As already mentioned, for ASM in strain N88 the estimates of participation of additive-by-additive genetic variance in total variance were largest $\left(h_{a n}^{2}=0.0785\right)$. Inclusion of the effect into the linear model caused an increase of heritability estimates $\left(h_{a}^{2}\right)$ from 0.0086 (simple model) to 0.2380 . Such a change is rather difficult to interpret since the same data-file and the same model (excluding additive-byadditive genetic effects) were employed. Age at sexual maturity was characterized by relatively small additive genetic and error variance component estimates. Hence, it seems that from a numerical point of view the estimated function of these variance components may be biased due to some approximations.

The obtained estimates of variance components and heritabilities require also looking into data transformation results. Data transformation resulted in an increase of heritability estimates, while a decrease of both additive and additive-by-additive genetic variance estimates was usually observed. However, in the case of AEW (for H77) as well as BW and IEP (for N88) a significant increase of all variance estimates was noticed, which leads, in consequence, to an increase of heritability estimates. Basically, the relations between magnitudes of variance component estimates before and after transformation are not directly connected with the skewness and kurtosis of trait distributions.

Dividing the observation results by the mean (for both untransformed and transformed data) allows comparison of the variance estimates between the traits and strains. Relatively large differences in variance components estimates within strains 
and traits were obtained. This points to the large impact of deviations from method and model assumptions (particularly trait distributions) on the magnitude of variances and heritability estimates.

\section{CONCLUSIONS}

The present analysis suggests that additive-by-additive epistasis effects are not important for performance traits in both laying hen strains. Thus, according to earlier results (Szwaczkowski, 1995), the nonadditive genetic effects may be ignored in the linear model for genetic evaluations.

The results indicate that deviations from trait normality strongly influenced the magnitude of variance component estimates (however, not only the error variance estimate was modified). It was confirmed that transformation of data to normality increased heritability estimates.

\section{ACKNOWLEDGMENTS}

Author is grateful to Dr. Rudolf Preisinger for useful comments, Dr. Karin Meyer for providing her DFREML programs and Mr. Henryk Czeluśniak for helping in data preparation and providing the computer program to calculate the inversion of additive-by-additive relationship matrix. The computations were performed at the Poznan Supercomputer and Networing Center.

\section{REFERENCES}

Abplanalp H., Okamoto S., Napolitano D., Len R.E., 1984. A study of heterosis and recombination losses in crosses in inbred Leghorn line derived from a common base population. Poultry Sci. 63, 234-239

Besbes B., Ducrocq V., Foulley J.L., Protais M., Tavernier A., Tixer-Boichard M., Beaumont C., 1992. Estimation of genetic parameters of egg production traits of laying hens by restricted maximum likelihood applied to a multiple-trait reduced animal model. Genet. Sel. Evol. 24, $539-552$

Box G.E.P., Cox D.R., 1964. An analysis of transformations. J. Royal Statist. Soc. B, 26, 211-243

Eisen E.J., Bohren B.B., McKean H.E., King S.C., 1967. Combining ability among single crosses and predicting double cross performances in poultry. Brit. Poultry Sci. 8, 231-242

Fairfull R.W., Gowe R.S., Emsley J.A.B., 1983. Diallel cross of six long-term selected Leghorns strains with emphasis on heterosis and reciprocal effects. Brit. Poultry Sci. 24, 133-158

Fairfull R.W., Gowe R.S., 1993. Heterosis. In: R.D. Crawford (Editor). Poultry Breeding and Genetics. Elsevier, Amsterdam 
Flock D.K., Ameli H., Glodek P., 1991. Inbreeding and heterosis effects on quantitative traits in a White Leghorn population under long-term reciprocal recurrent selection. Brit. Poultry Sci. 32, 451-462

Fuerst C., Soelkner J., 1994. Additive and nonadditive variances for milk yicld, fertility, and lifetime performance traits of dairy cattle. J. Dairy Sci. 77, 1114-1125

Graser H.U., Smith S.P., Tier B., 1987. A derivative-free approach for estimating variance components in animal models by restricted maximum likelihood. J. Anim. Sci. 64, 1362-1370

Henderson C.R., 1988. Theoretical basis and computional methods for a number of different animal models. J. Dairy Sci. 71, Suppl. 2, 1-16

Hoeschele I., 1991. Additive and nonadditive genetic variance in female fertility of Holstein. J. Dairy Sci. $74,1743-1752$

Lin C.Y., Lee A.J., 1989. Estimation of additive and nonadditive genetic variances in noninbred populations under sire or fullsib model. Can. J. Anim. Sci. 69, 61-68

Meyer K., 1989. Restricted maximum likelihood to estimate variance components for animal models with several random effects using a derivative-free algorithm. Genet. Sel. Evol. 21, 317-340

Meyer K. 1993. Programs to estimate variance components for individual animal models by restricted maximum likelihood (REML). User notes. Institute of Animal Genetics, Edinburgh University, Edinburgh

Patterson H.D., Thompson R., 1971. Recovery of interblock information when block sizes are unequal. Biometrika 58, 545-554

Quaas R.L., Pollak E.J., 1980. Mixed model methodology for farm and ranch beef cattle testing programs. J. Anim. Sci. 58, 1097-1106

Rabsztyn A., 1990. Genetic parameters of purebred Rhode Island Red and Barred Rock hen strains and their reciprocal crossbreds. Genet. Pol. 31, 129-135

Raden Van P.M., Hocschele 1., 1991. Rapid inversion of additive by additive relationship matrices by including sire-dam combination effects. J. Dairy Sci. 74, 570-579

Sheridan A.K., Randall M.C., 1977. Heterosis for egg production in White Leghorn-Australorp crosses. Brit. Poultry Sci. 18, 69-77

Strabel T., Szwaczkowski T., 1997. Additive genetic and permanent environmental variance components for test day milk traits in Black-White cattle. Livest. Prod. Sci. 48, 91-98

Szwaczkowski T., 1995. An analysis of the genetic determination of the performance traits in laying hens (in Polish). Rocz. Akad. Rol. Poznań, No 260

Szzaczkowski T., Wężyk S., 1994. Estimation of the heritability with animal model - REML for performance traits in laying hens. Rocz. Nauk. Zoot. 21, 33-39

Tempelman R.J., Burnside E.B., 1990. Additive and nonadditive genetic variation for production traits in Canadian Holstein. J. Dairy Sci. 73, 2206-2213

Wei M., Van Der Werf J.H.J., 1993. Animal model estimation of additive and dominance variances in egg production traits of poultry. J. Anim. Sci. 71, 57-65

Wężyk S., 1978. SELEKT system for pedigree poultry flocks (in Polish). Wyniki Prac Badawczych, Department of Poultry Breeding; Results of Investigations in 1974-76. Institute of Animal Production, Kraków (Poland) 7, 7-18

Wężyk S., Szwaczkowski T., 1997. Application of mixed model methodology in breeding strategies for laying fowl. World Poultry Sci. J. 53, 325-336 


\section{STRESZCZENIE}

\section{Zmienność genetyczna addytywna i epistatyczna typu addycja $x$ addycja cech użytkowych kur nieśnych}

W pracy szacowano wariancje bezpośrednie genetyczne addytywne i bezpośrednie epistatyczne dla par loci o działaniu addytywnym cech użytkowych (masy ciała, wieku osiągania dojrzałości płciowej, nieśności początkowej oraz masy jaja) dwóch rodów kur nieśnych (H77 i N88). Analizą objęto 8035 osobników pochodzących z 11 pokoleń. Szacowanie komponentów wariancji bazującą na algorytmie DFREML poprzedzono wstępną analizą danych obejmującą modelowanie efektów stałych i zmiennych kowariancyjnych oraz transformację danych. Obliczenia przeprowadzono stosując jednocechowy model zwierzęcia tak dla danych transformowanych jak i nietransformowanych. W zasadzie wszystkie oszacowane wariancje epistatyczne były bardzo bliskie zeru. Stwierdzono nieukierunkowany wpływ odchyleń od normalności rozkladu cech na wielkość estymatorów komponentów wariancji. Transformacja danych $\mathrm{z}$ reguły prowadziła jednak do wzrostu estymatorów odziedziczalności. 